\title{
Model Recommendation Creation for New Entrepreneur using TOPSIS Method in Bandung Raya
}

DOI:10.36909/jer.ASSEEE.16101

\author{
Angga Setiyadi*, Eko Budi Setiawan \\ *Departemen Teknik Informatika, Universitas Komputer Indonesia, Indonesia \\ Corresponding Author : angga.setiyadi@email.unikom.ac.id
}

\begin{abstract}
The purpose of the research is to help new entrepreneurs make decisions in choosing and opening a business that best suits their needs so that it can facilitate marketing, which will impact increasing product sales, new entrepreneurs. The research method used in this research is a quantitative descriptive analysis that describes facts and information. The decision-making method in this study used the technique for order preference by similarity to ideal solution (TOPSIS). This research uses a case study of the community in the Ngamprah sub-district and will open a business in the Ngamprah sub-district. The results obtained from this study are that new business actors in the Ngamprah sub-district are recommended to take the type of business, for the first order is business in publishing and printing, second place is business in the advertising sector and the order. The third is the architecture business. The use of the method in this study can provide recommendations in decision making to determine new entrepreneurs in Bandung Raya. In addition to providing recommendations for new entrepreneurs, it can be easier to make decisions to determine the business that will be opened.
\end{abstract} Keywords: TOPSIS, entrepreneurs, business, sub-district.

\section{INTRODUCTION}

Entrepreneurship is an effort to build a business or employment independently based on innovation and unique creativity so that you can generate financial benefits. Many economists claim that entrepreneurial activity is very important for the progress of the country's economy 
(Haidar, 2012; Van Stel et al., 2055). Based on the Indonesian Ministry of Industry in 2018, Indonesia needs at least four million new entrepreneurs to help strengthen the domestic economic structure. The Indonesian government is spurring the growth of entrepreneurs, including small and medium industries, as well as increasing productivity and competitiveness in the digital era (Kemenperin, 2018).

There are several factors for entrepreneurship to develop, including business conditions, environment, infrastructure, and technology (Setiyadi \& Agustia, 2018). Bandung city is the third-largest city in Indonesia after Jakarta and Surabaya. Bandung city has about two point five million inhabitants (Tarigan et al., 2016). The city of Bandung currently has many places to produce new entrepreneurs, one of which is a training center for cooperatives and micro, small and medium enterprises under the auspices of the cooperative and umkm office. It has a role as a business clinic in solving cooperatives and micro, small and medium enterprises (Setiyadi \& Setiawan, 2020; Kurniasih \& Setiyadi, 2019).

Business actors can open many businesses, but many of them are still confused about opening a business that they are going to do. Business actors must make decisions to open a business that best suits their needs and circumstances. Decision-making is a process of selecting alternative actions to achieve certain goals or objectives (Setiyadi \& Agustia, 2018; Al Shra'ah, 2015; Lunenburg, 2010).

Many approaches can be used in decision support systems. One of the methods used the TOPSIS (Technique for order preference by similarity to ideal solution) method. The TOPSIS method is widely used to solve problems in practical decision-making (Diana, 2018). Topsis is widely used in research for decision-making in various fields. Several other studies have also implemented the TOPSIS method, including the TOPSIS method used for internal control to select the best employees (Rahim et al., 2018). TOPSIS method is used to select outstanding students (Sucipto \& Wibisono, 2019), TOPSIS method is used for cargo delivery (Gurning et al., 2017). Based on the brief explanation previously described, it was found that research needs to be carried out to help new entrepreneurs in making decisions. Besides, in choosing and 
opening a business that best suits their needs to facilitate marketing, which will impact increasing the sales results of micro business actors small and medium.

\section{EXPERIMENTAL METHOD}

The research method used in this research is a quantitative descriptive analysis that will describe the facts and information to provide a clear picture of the research carried out by emphasizing quantitative data as a benchmark for the study (Setiyadi \& Setiawan, 2018). In this study, the method used is Technique for order preference by similarity to the ideal solution, which is modeled to help new entrepreneurs choose the most suitable business based on several assessment criteria and alternatives given.

The first method is Formulating research problems. The researcher conducted a preliminary study of the object under study through empirical facts obtained from several references; the second method is Theoretical references are needed to answer the formulation of problems in research. Literature studies are needed as input to provide temporary answers to the formulation of research problems (Setiawan \& Setiyadi, 2018; Setiyadi \& Setiawan, 2019; Priladha \& Setiyadi, 2019). The third method is The topsis stage consists of ten stages. the fourth method aims to process the data obtained and conduct tests using the technique for order preference by similarity to an ideal solution. the fifth method is the final stage of the research carried out, which will obtain recommendations for opening a business with the highest priority that new entrepreneurs in marketing their products will use. Meanwhile, suggestions are made so that future research can improve the deficiencies in this research.

The research framework is a research design used as a guide in conducting the research process so that research is carried out and can run well and systematically. The research framework used in the research carried out can be seen in Figure 1. 


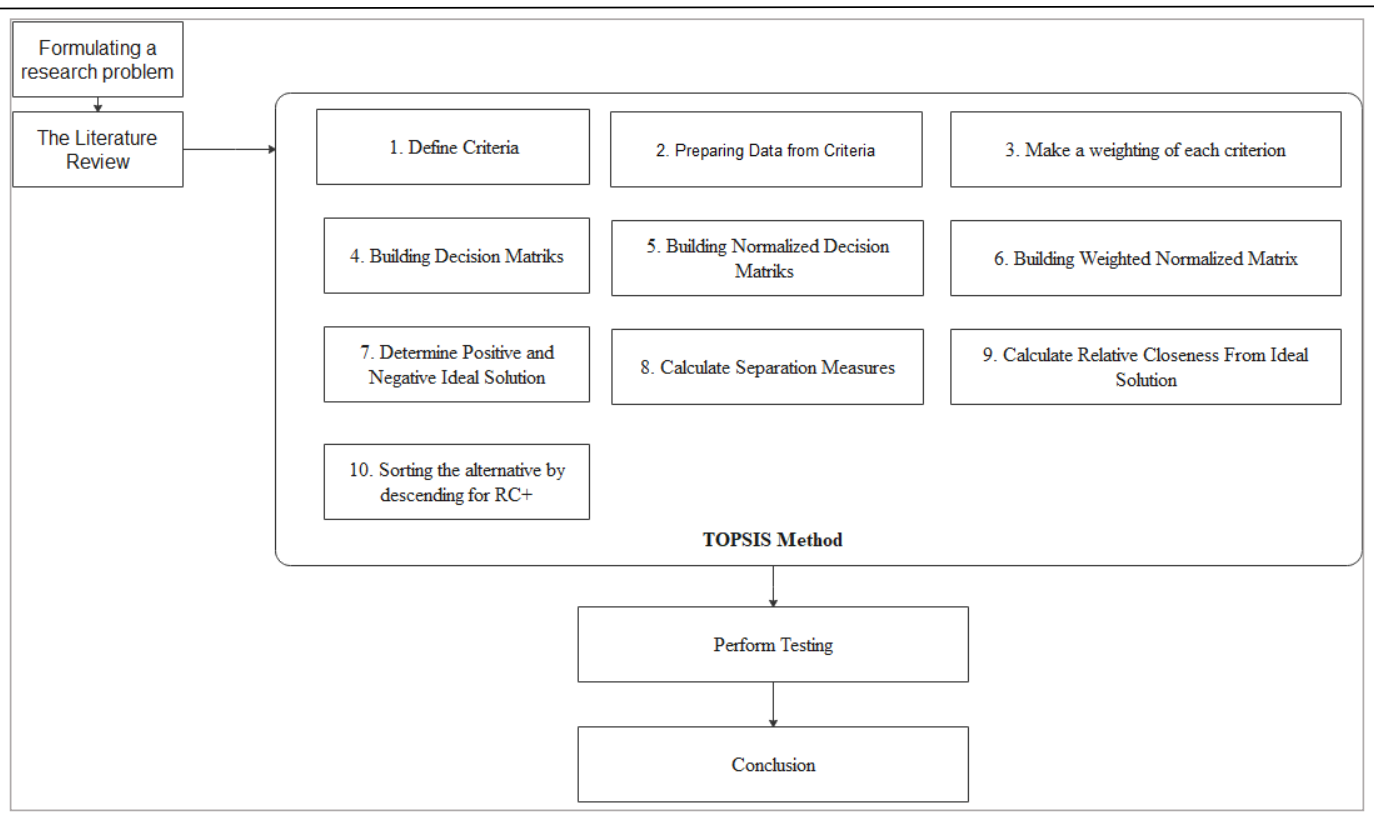

Figure 1 Location of Research, Sukajadi Street

\section{RESULTS AND DISCUSSION}

\section{Data Analysis for New Business Actors}

Data analysis of new business actors aims to see data that can be used to determine criteria in the technique preference by similarity to ideal solution. The following is the output screen of the new entrepreneurial database, which can be seen in Figure 2.

\begin{tabular}{|c|c|c|c|c|c|}
\hline \multicolumn{2}{|l|}{ alamat_usaha } & rt_2 & $r w \_2$ & id_kab_kot_2 & id_kecamata \\
\hline Kp. Pameutingan No. 1 & $21 \mathrm{~B}$ & 2 & 9 & 3204 & 3217100 \\
\hline Jl. Cikutra Gg. Sukanegla & $25 B$ & 2 & 5 & 3273 & 3217100 \\
\hline Taman Cibaduyut Indah Blok D No.9 & 33B & 6 & 16 & 3204 & 3217100 \\
\hline Puri Cikoneng & 13B & 2 & 7 & 3204 & 3217100 \\
\hline Komp. Vijaya Kusuma A.14 no. 20 & $31 \mathrm{~B}$ & 7 & 17 & 3273 & 3217100 \\
\hline J1.Ahmadi Utara & $15 B$ & 2 & 7 & 3204 & 3217100 \\
\hline
\end{tabular}

Figure 2 Database of new business actors.

\section{Analysis of Business Types for New Business Actors}

Analysis, The type of business analysis aims to map the types of businesses that can be used for new entrepreneurs. There are fifteen types of businesses that can be used as business alternatives that new entrepreneurs can use. The following are types of businesses that can be used by new entrepreneurs, as seen in Table 1 . 
Table 1 Analysis of Business Types for New Business Actors.

\begin{tabular}{|c|c|c|c|}
\hline No & Business Alternative & No & Business Alternative \\
\hline 1 & Advertising & 9 & Music \\
\hline 2 & Architecture & 10 & Performing Arts \\
\hline 3 & Art Goods Market & 11 & Publishing and Printing \\
\hline 4 & Craft & 12 & Computer Services and Software \\
\hline 5 & Design & 13 & Television and Radio \\
\hline 6 & Fashion & 14 & Research and development \\
\hline 7 & Video, Film, and Photography & 15 & Culinary \\
\hline 8 & Interactive Games & \multicolumn{2}{c}{} \\
\cline { 1 - 2 } & \multicolumn{2}{|r}{} &
\end{tabular}

\section{New Entrepreneur Creation Model Case Study}

Udin is a community that lives in Ngamprah District, West Bandung Regency. Udin will open a business in Ngamprah District, West Bandung Regency; the following are recommendations for determining a business.

\section{Analysis of Determination Criteria}

Analysis of criteria determination aims to determine data that can be used to determine new entrepreneurial ventures. The following are the criteria for determining the business in the Ngamprah District, West Bandung Regency, which can be seen in Table 2.

Table 2 Analysis of Determination Criteria.

\begin{tabular}{|l|l|}
\hline No Criteria & \multicolumn{1}{c|}{ Criteria } \\
\hline C1 & Number of Sectors in the region \\
\hline C2 & Total assets in the region \\
\hline C3 & Total Employees in the area \\
\hline C4 & Average year of starting a business in the region \\
\hline
\end{tabular}

\section{Calculating the Total Criteria in The Area}

Calculating the total criteria aims to get the total data in one district based on predetermined criteria. The following is the SQL syntax for calculating the total criteria in the area, as shown in Figure 3. 


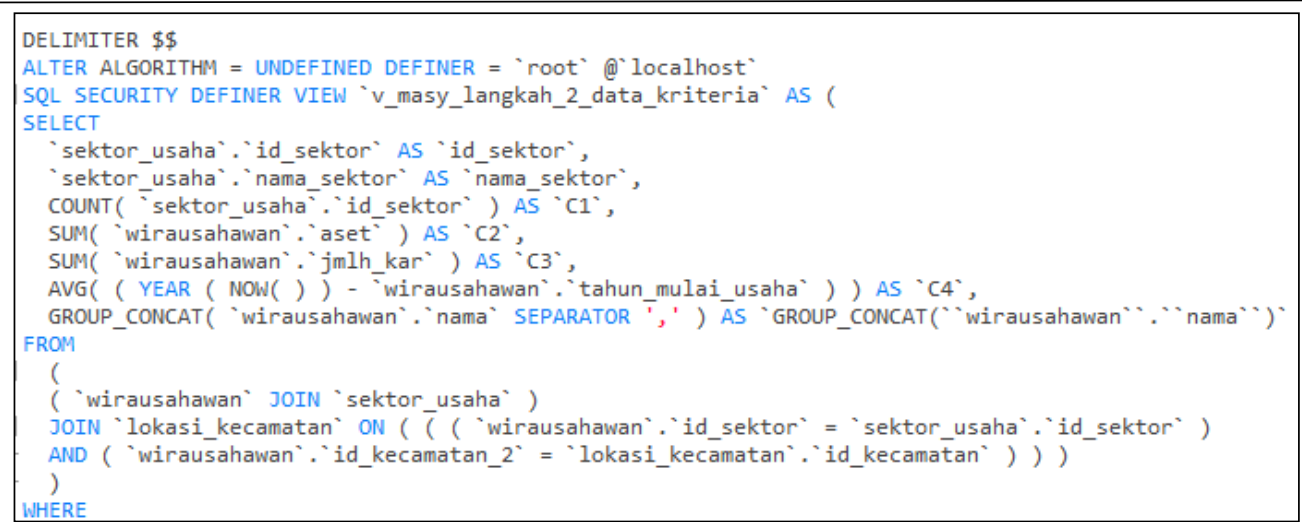

Figure 3 SQL syntax to calculate total criteria in an area.

Based on the SQL syntax to calculate the total criteria in the area, Based on the SQL syntax in figure 3, there are fifteen business sectors, The following is the output screen of the SQL syntax execution result to calculate the total criteria can be seen in Figure 4.

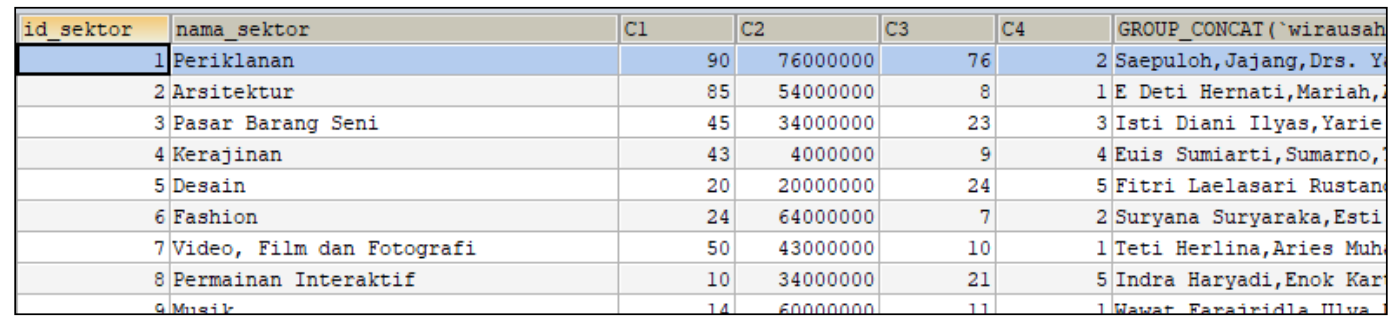

Figure 4 Output results from the calculation of the total criteria.

\section{Make a Weighting for each Criterion}

The weighting of the topsis method aims to provide the value of each parameter in the criteria. The weighting of the topsis method aims to provide the value of each parameter in the criteria. The following is the output screen of the weighting of each criterion can be seen in Figure 5.

\begin{tabular}{|r|l|l|l|l|}
\hline id & sub_parameter & bobot & keterangan & satuan \\
\hline 6 & 0 & Tahun (Ide Bisnis) & 1 tahun_mulai_usaha & tahun \\
\hline 7 & $1-2$ Tahun (Start Up) & 3 tahun_mulai_usaha & tahun \\
\hline 8 & $3-5$ Tahun (Growth) & 6 tahun_mulai_usaha & tahun \\
\hline 9 & $1-5$ Orang & 1 Jumlah Karyawan & orang \\
\hline 10 & $6-10$ Orang & 3 & Jumlah Karyawan & orang \\
\hline 11 & $>11$ Orang & 6 Jumlah Karyawan & orang \\
\hline 12 & $1-5$ Juta & 0.5 & Aset Pertahun & Juta \\
\hline 13 & $6-10$ Juta & 1 Aset Pertahun & Juta \\
\hline 14 & $11-20$ Juta & 1.25 & Aset Pertahun & Juta \\
\hline 15 & $21-50$ Juta & 1.5 & Aset Pertahun & Juta \\
\hline 16 & $51-100$ Juta & 2 Aset Pertahun & Juta \\
\hline
\end{tabular}

Figure 5 The results of the weighted value of each criterion. 


\section{Building a Decision Matrix}

The decision matrix development aims to map the value of the type of business and the value of the criteria. The decision matrix development equation is as follows:

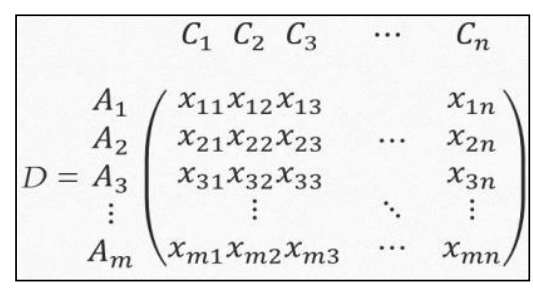

In making a decision matrix, there are three fields used, the three names in each field are given the name c1. The following is the SQL syntax to map the value of the type of business, and the criterion value to the value $\mathrm{c} 1$ can be seen in Figure 6.

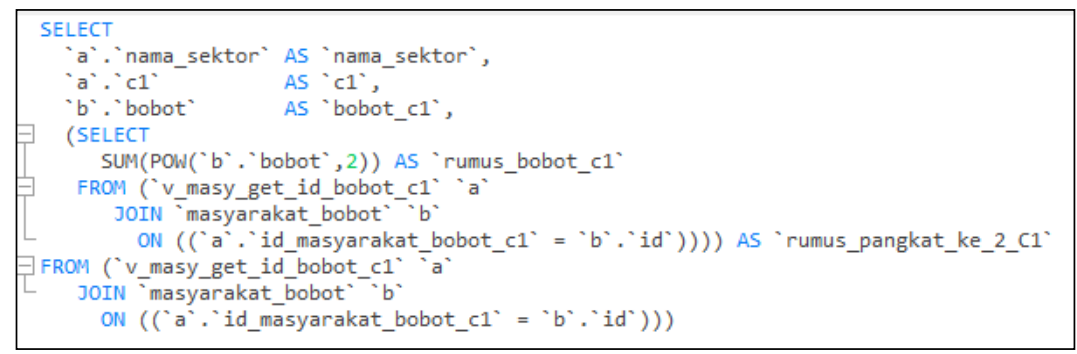

Figure 6 The SQL syntax for constructing a decision matrix for the value of $\mathrm{c} 1$.

Based on the sql syntax to map the value of the type of business and the value of the criteria to the value of $\mathrm{c} 1$ and Based on the SQL syntax to map the value of the type of business and the value of the criteria. The output screen mapping the value of the type of business and the value of the criteria to the value of $\mathrm{c} 1$ can be seen in Figure 7.

\begin{tabular}{|l|r|r|r|r|}
\hline nama_sektor & cl & & bobot_cl & rumus_pangkat_ke_2_Cl \\
\hline Periklanan & 90 & 3 & 55 \\
\hline Arsitektur & 85 & 3 & 55 \\
\hline Pasar Barang Seni & 45 & 1 & 55 \\
\hline Kerajinan & 43 & 1 & 55 \\
\hline Desain & 20 & 1 & 55 \\
\hline Fashion & 24 & 1 & 55 \\
\hline Video, Film dan Fotografi & 50 & 3 & 55 \\
\hline Permainan Interaktif & 10 & 1 & 55 \\
\hline
\end{tabular}

Figure 7 The output of the decision matrix development for the value of $\mathrm{c} 1$. 


\section{Building Normalized Decision Matrix}

The next step is to build a normalized decision matrix with the following equation:

$$
\left.\begin{array}{ccccc|}
\hline & C_{1} C_{2} C_{3} & \cdots & C_{n} \\
A_{1} & r_{11} r_{12} r_{13} & & r_{1 n} \\
A_{2} & r_{21} r_{22} r_{23} & \cdots & r_{2 n} \\
R= & A_{3} & r_{31} r_{32} r_{33} & & r_{3 n} \\
\vdots & \vdots & \ddots & \vdots \\
A_{m} & r_{m 1} r_{m 2} r_{m 3} & \cdots & r_{m n}
\end{array}\right) \quad r_{i j}=x_{i j} *\left(\sum_{i=1}^{m} x_{i j}^{2}\right)^{-1 / 2}
$$

The merger of several view tables created in the previous step used SQL syntax to build a normalized decision matrix. The following is the sql syntax for building a normalized decision matrix in Figure 8.

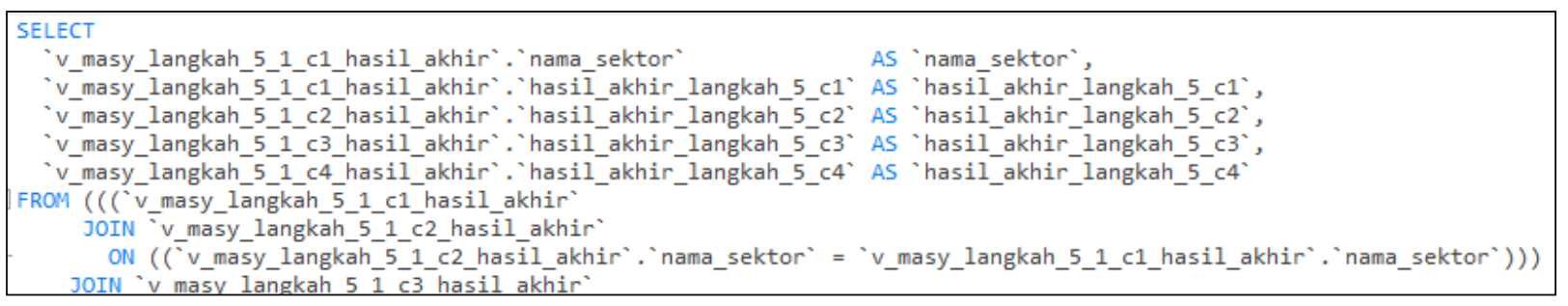

Figure 8 The output results of the normalized decision matrix development.

In making a normalized decision matrix, there are five fields used. Based on the SQL syntax to build a normalized decision matrix, the following is the output screen of building a normalized decision matrix, seen in Figure 9.

\begin{tabular}{|l|r|r|r|r|}
\hline nama_sektor & hasil_akhir_langkah_5_c1 & hasil_akhir_langkah_5_c2 & hasil_akhir_langkah_5_c3 & hasil_akhir_1... \\
\hline Periklanan & 0.40452 & 0.28535 & 0.30861 & 0.15430 \\
\hline Arsitektur & 0.40452 & 0.28535 & 0.15430 & 0.15430 \\
\hline Pasar Barang Seni & 0.13484 & 0.21401 & 0.30861 \\
\hline Kerajinan & 0.13484 & 0.07134 & 0.30861 & 0.15430 \\
\hline Desain & 0.13484 & 0.17834 & 0.30861 \\
\hline Fashion & 0.13484 & 0.28535 & 0.30861 \\
\hline Video, Film dan Fotografi & 0.40452 & 0.21401 & 0.15430 \\
\hline Permainan Tnteraktif & 0.13484 & 0.21401 & 0.15430 & 0.15430 \\
\hline
\end{tabular}

Figure 9 The output result of normalized decision matrix development.

\section{Building Weight Normalized Decision Matrix}

The next step is to build a weight normalized decision matrix with the following equation:

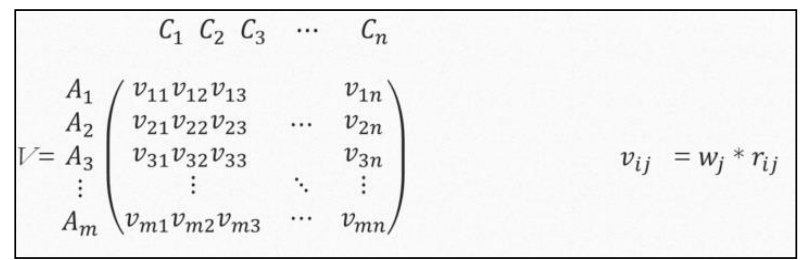


The SQL syntax to build a weight normalized decision matrix on a percentage will result in a hundred. The following is the sql syntax for building a weight normalized decision matrix, as shown in Figure 10.

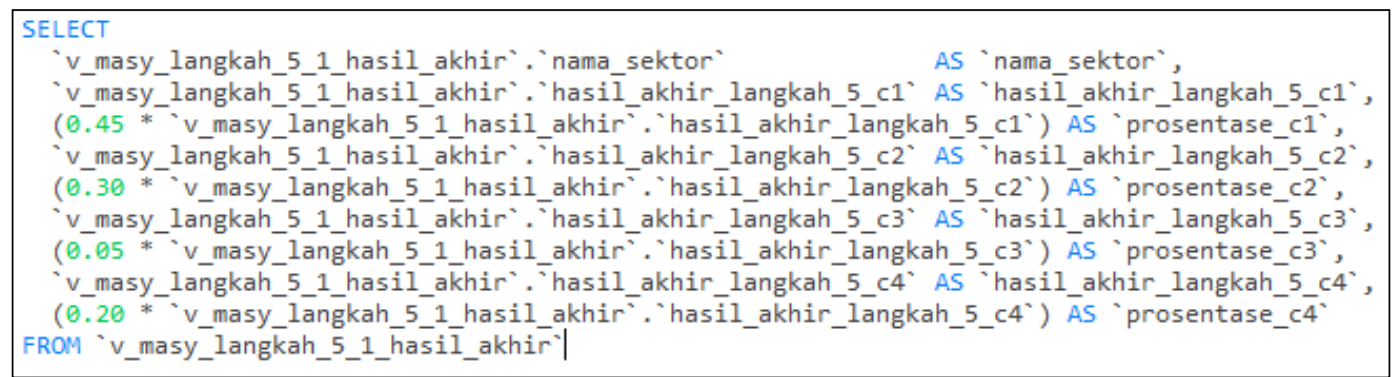

Figure 10 The output results of the weight normalized decision matrix development.

Determination of the weight normalized decision matrix consists of nine fields. Nine fields are used to determine the weight of the normalized decision matrix. Based on the SQL syntax to build a normalized decision matrix, the following is the output screen of building a normalized decision matrix, seen in Figure 11.

\begin{tabular}{|c|c|c|c|c|c|}
\hline nama_sektor & hasil_akhir_langkah_5_cl & prosentase_cl & hasil_akhir_langkah_5_c2 & prosentase_c2 & hasil_akhir_langkah_5 \\
\hline Periklanan & 0.40452 & 0.18203 & 0.28535 & 0.08561 & 0. \\
\hline Arsitektur & 0.40452 & 0.18203 & 0.28535 & 0.08561 & 0. \\
\hline Pasar Barang Seni & 0.13484 & 0.06068 & 0.21401 & 0.06420 & 0. \\
\hline Kerajinan & 0.13484 & 0.06068 & 0.07134 & 0.02140 & 0. \\
\hline Desain & 0.13484 & 0.06068 & 0.17834 & 0.05350 & 0. \\
\hline Fashion & 0.13484 & 0.06068 & 0.28535 & 0.08561 & 0. \\
\hline Video, Film dan Fotografi & 0.40452 & 0.18203 & 0.21401 & 0.06420 & 0. \\
\hline Permainan Interaktif & 0.13484 & 0.06068 & 0.21401 & 0.06420 & 0. \\
\hline Musik & 0.13484 & 0.06068 & 0.28535 & 0.08561 & 0. \\
\hline
\end{tabular}

Figure 11 The output results of the weight normalized decision matrix development.

\section{Determine Positive and Negative Ideal Solution}

The next step is to determine the positive (PIS A +) and negative (NIS A-) ideal solutions with the following equation.

$$
\begin{aligned}
& \text { - } \mathrm{PIS}=A^{+}=\left\{\begin{array}{c}
\text { Max } \\
i
\end{array} v_{i j} ; \mathrm{j} \in \mathrm{J}\right\}=\left\{v_{1}^{+}, v_{2,}^{+}, v_{3}^{+}, \ldots, v_{m}^{+}\right\} \\
& \text {- } \mathrm{NIS}=A^{+}=\left\{\begin{array}{c}
\text { Min } \left.v_{i j} ; \mathrm{j} \in \mathrm{J}\right\}=\left\{v_{1}^{-}, v_{2}^{-}, v_{3}^{-}, \ldots, v_{m}^{-}\right\} \\
i
\end{array}\right.
\end{aligned}
$$

SQL syntax to determine positives and negatives for each field is obtained by determining the highest and lowest values of the weight normalized decision matrix for each field. The 
following is the sql syntax to determine positive (PIS A +) and negative (NIS A-) shown in Figure 12.

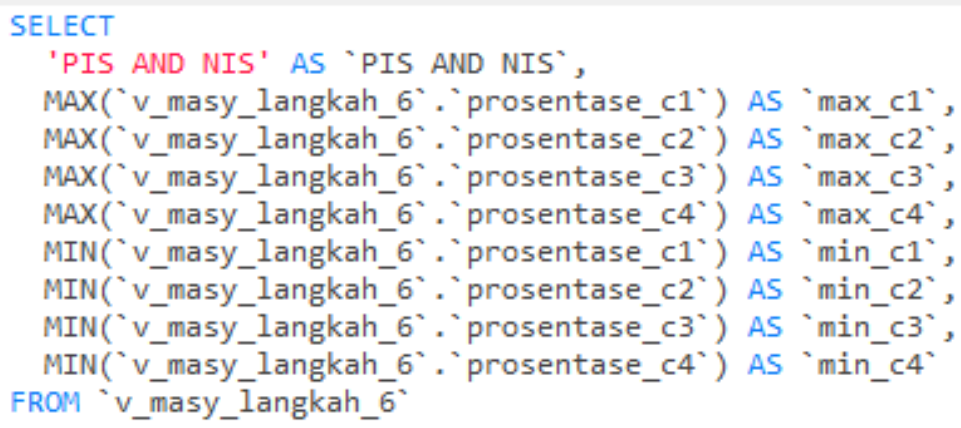

Figure 12 Output sql syntax to determine positive and negative.

There are eight fields used, including the fields to find the largest value from $\mathrm{c} 1$ to $\mathrm{c} 4$ and the fields used to find the smallest value from $\mathrm{c} 1$ to $\mathrm{c} 4$. The following is the output screen of building a normalized decision matrix in Figure 13.

\begin{tabular}{|c|c|c|c|c|c|c|c|c|}
\hline PIS AND NIS & max_cl & max_c2 & $\max \_c 3$ & max_c4 & min_cl & min_c2 & min_c3 & min_c4 \\
\hline PIS AND NIS & 0.18203 & 0.16051 & 0.01543 & 0.06172 & 0.06068 & 0.02140 & 0.00771 & 0.03086 \\
\hline & (NULL) & (NULL) & (NULL) & (NULL) & (NULL) & (NULL) & (NULL) & (NULL) \\
\hline
\end{tabular}

Figure 13 Output results for determining positive (PIS A +) and negative (NIS A-).

\section{Calculate Separation Measures}

The next step is to calculate separation measures with an equation like the following:

$$
\begin{aligned}
& D_{i}^{+}=\left\{\sum_{j=1}^{n}\left(v_{i j}-v_{j}^{+}\right)^{2}\right\}^{1 / 2}, 1 \leq i \leq m \\
& D_{i}^{-}=\left\{\sum_{j=1}^{n}\left(v_{i j}-v_{j}^{-}\right)^{2}\right\}^{1 / 2}, 1 \leq i \leq m
\end{aligned}
$$

Calculate the separation step used to find the value of determining the positive value and the negative ideal solution in the previous step. The following is a piece of sql syntax for calculating separation measures shown in Figure 14. 


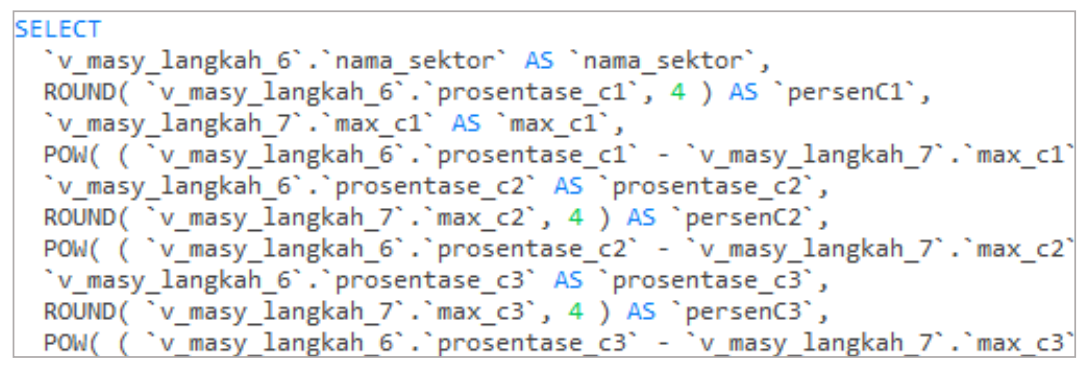

Figure 14 Output SQL syntax fragment for calculating separation measures.

The SQL syntax separation calculation consists of sixteen fields. For category c1, the percentage field $\mathrm{c} 1$ has a value of 0.1820 . Based on the SQL syntax fragment to calculate separation measures, the following is the output screen of separation measures shown in Figure 15.

\begin{tabular}{|l|r|r|r|r|r|r|r|}
\hline nama_sektor & persenC1 & max_c1 & hasil_sm_c1 & prosentase_c2 & persenC2 & hasi1_sm_c2 & p \\
\hline Periklanan & 0.1820 & 0.18203 & 0 & 0.08561 & 0.1605 & 0.005610609216 \\
\hline Arsitektur & 0.1820 & 0.18203 & 0 & 0.08561 & 0.1605 & 0.005610609216 \\
\hline Pasar Barang Seni & 0.0607 & 0.18203 & 0.014727278736 & 0.06420 & 0.1605 & 0.009274845636 \\
\hline Kerajinan & 0.0607 & 0.18203 & 0.014727278736 & 0.02140 & 0.1605 & 0.019350757449 \\
\hline Desain & 0.0607 & 0.18203 & 0.014727278736 & 0.05350 & 0.1605 & 0.011450498049 \\
\hline Fashion & 0.0607 & 0.18203 & 0.014727278736 & 0.08561 & 0.1605 & 0.005610609216 \\
\hline Video, Film dan Fotografi & 0.1820 & 0.18203 & 0 & 0.06420 & 0.1605 & 0.009274845636 \\
\hline Permainan Interaktif & 0.0607 & 0.18203 & 0.014727278736 & 0.06420 & 0.1605 & 0.009274845636 \\
\hline
\end{tabular}

Figure 15 Output results for calculating separation measures.

\section{Calculate relative closeness from the ideal solution}

The next step is to calculate the relative closeness of the ideal solution with the following equation.

$$
R C_{i}^{+}=\frac{D_{i}^{-}}{D_{i}^{-}+D_{i}^{+}}, 1 \leq i \leq m
$$

In this section, the relative computation of the ideal solution will be calculated. The following is a fragment of the sql syntax to calculate relative closeness, as shown in Figure 16.

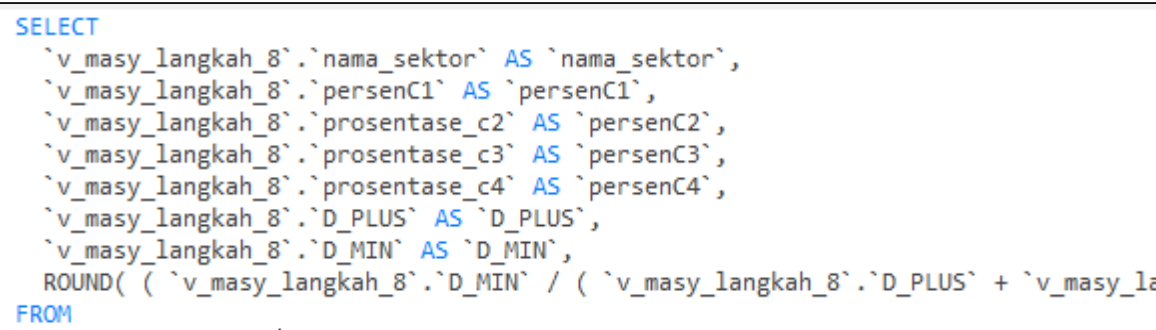

Figure 16 The output of the sql syntax fragment for the relative closeness of the ideal solution. 
Based on the sql syntax that has been made in the calculation of relative closeness from the ideal solution consisting of eight parts, c1,c2, c3 and c4 are made into a percentage, the value of $\mathrm{D}+$, the value of $\mathrm{D}$ - and the value of the ideal solution. The following is the output screen of the relative closeness of the ideal solution, which can be seen in Figure 17.

\begin{tabular}{|l|r|r|r|r|r|r|r|r|r|r|r|r|r|r|r|r|r|}
\hline nama_sektor & persenC1 & persenC2 & persenC3 & persenC4 & D_PLUS & D_MIN & RC_plus \\
\hline Periklanan & 0.1820 & 0.08561 & 0.01543 & 0.03086 & 0.0810 & 0.1375 & 0.6293 \\
\hline Arsitektur & 0.1820 & 0.08561 & 0.00771 & 0.03086 & 0.0814 & 0.1373 & 0.6278 \\
\hline Pasar Barang Seni & 0.0607 & 0.06420 & 0.01543 & 0.06172 & 0.1549 & 0.0533 & 0.2560 \\
\hline Kerajinan & 0.0607 & 0.02140 & 0.00771 & 0.06172 & 0.1848 & 0.0309 & 0.1433 \\
\hline Desain & 0.0607 & 0.05350 & 0.01543 & 0.06172 & 0.1618 & 0.0452 & 0.2184 \\
\hline Fashion & 0.0607 & 0.08561 & 0.00771 & 0.03086 & 0.1461 & 0.0642 & 0.3053 \\
\hline Video, Film dan Fotografi & 0.1820 & 0.06420 & 0.00771 & 0.03086 & 0.1014 & 0.1287 & 0.5593 \\
\hline Permainan Interaktif & 0.0607 & 0.06420 & 0.01543 & 0.06172 & 0.1549 & 0.0533 & 0.2560 \\
\hline Musik & 0.0607 & 0.08561 & 0.01543 & 0.03086 & 0.1459 & 0.0647 & 0.3072 \\
\hline
\end{tabular}

Figure 17 Output for calculating the relative closeness of an ideal solution.

\section{Sorting the Alternative by Descending for $\mathrm{RC}+$}

This step is the final step of determining the recommendation and sorting the descending alternatives for $\mathrm{RC}+$. The following is the sql syntax for calculating relative closeness, as shown in Figure 18.

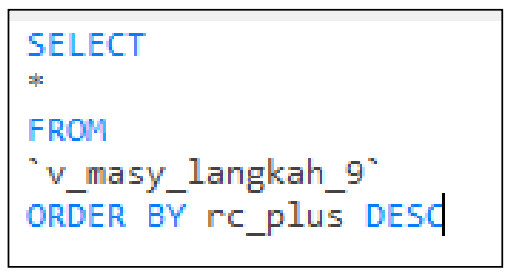

Figure 18 The output of the sql syntax fragment to sort descending alternative solutions for $\mathrm{RC}+$.

Based on the SQL syntax fragment to sort descending alternative solutions for $\mathrm{RC}+$, The results obtained from the descending order of $\mathrm{RC}+$ for the first rank are publishing and printing with an $\mathrm{RC}+$ value of zero point six five two nine. The following is the output screen of sorting descending alternative solutions for RC + in Figure 19. 


\begin{tabular}{|l|r|r|r|r|r|r|r|r|r|r|r|r|r|r|r|r|r|}
\hline nama_sektor & persenC1 & persenC2 & persenC3 & persenC4 & D_PLUS & D_MIN & RC_plus \\
\hline Penerbitan dan Percetakan & 0.1820 & 0.08561 & 0.01543 & 0.06172 & 0.0749 & 0.1409 & 0.6529 \\
\hline Periklanan & 0.1820 & 0.08561 & 0.01543 & 0.03086 & 0.0810 & 0.1375 & 0.6293 \\
\hline Arsitektur & 0.1820 & 0.08561 & 0.00771 & 0.03086 & 0.0814 & 0.1373 & 0.6278 \\
\hline Video, Film dan Fotografi & 0.1820 & 0.06420 & 0.00771 & 0.03086 & 0.1014 & 0.1287 & 0.5593 \\
\hline Kuliner & 0.0607 & 0.16051 & 0.00771 & 0.06172 & 0.1216 & 0.1425 & 0.5396 \\
\hline Layanan Komputer dan Piranti Lunak & 0.1820 & 0.04280 & 0.01543 & 0.06172 & 0.1177 & 0.1273 & 0.5196 \\
\hline Musik & 0.0607 & 0.08561 & 0.01543 & 0.03086 & 0.1459 & 0.0647 & 0.3072 \\
\hline Fashion & 0.0607 & 0.08561 & 0.00771 & 0.03086 & 0.1461 & 0.0642 & 0.3053 \\
\hline Permainan Interaktif & 0.0607 & 0.06420 & 0.01543 & 0.06172 & 0.1549 & 0.0533 & 0.2560 \\
\hline Televisi dan Radio & 0.0607 & 0.06420 & 0.01543 & 0.06172 & 0.1549 & 0.0533 & 0.2560 \\
\hline Seni Pertunjukan & 0.0607 & 0.06420 & 0.01543 & 0.06172 & 0.1549 & 0.0533 & 0.2560 \\
\hline Pasar Barang Seni & 0.0607 & 0.06420 & 0.01543 & 0.06172 & 0.1549 & 0.0533 & 0.2560 \\
\hline Desain & 0.0607 & 0.05350 & 0.01543 & 0.06172 & 0.1618 & 0.0452 & 0.2184 \\
\hline
\end{tabular}

Figure 19 Output for calculating the relative closeness of an ideal solution.

After calculating the various stages, Udin can provide recommendations for businesses that are suggested to be opened by Udin in the Ngamprah District, West Bandung Regency, which are publishing and printing, advertising, architectural business.

\section{CONCLUSION}

Based on the results of implementation and testing, it can be concluded that using the TOPSIS (Technique for order preference by similarity to ideal solution) method. It can provide recommendations in decision-making to determine the creation of new entrepreneurs in Bandung Raya, and provide recommendations for new entrepreneurs can make it easier to make decisions to determine the business to be opened.

\section{ACKNOWLEDGMENTS}

Thanks to UNIKOM and KEMENRISTEKDIKTI for help and support this research using grant Penelitian Riset Terapan with a multi-year contract number Number 7 / E / KPT / 2019 and Agreement / Contract Number 110 / SP2H / LT / DRPM / 2019, number 2898 / L4 / PP / 2019 and number 045 / SP / LPPM / UNIKOM / III / 2019 Fiscal Year 2020.

\section{REFERENCES}

Al Shra'ah, A. E. M. 2015. The impact of decision making styles on organizational learning: An Empirical study on the public manufacturing companies in Jordan. International Journal of Business and Social Science, 6(4): 55-61

Diana. 2018. Metode Dan Aplikasi Sistem Pendukung Keputusan. Yogyakarta: Deepublish.

Gurning, R. S., Busse, W., and Lubnan, M. 2017. Decision Making of Full Speed, Slow 
Steaming, Extra Slow Steaming and Super Slow Steaming using TOPSIS. International Journal of Marine Engineering Innovation and Research, 2(1): 41-50.

Haidar, J. I. 2012. The impact of business regulatory reforms on economic growth. Journal of the Japanese and international economies, 26(3): 285-307.

Kemenprin. 2018. Indonesia Butuh 4 Juta Wirausaha Baru Untuk Menjadi Negara Maju. Kementrian Perindustrian Indonesia. Https://kemenperin.go.id/artikel/19926/indonesiabutuh-4-juta-wirausaha-baru-untuk-menjadi-negara-maju (Accessed Dec. 15, 2020).

Kurniasih, D., and Setiyadi, A. 2019. Geographic Information System for Mapping New Entrepreneurs in West Java. In IOP Conference Series: Materials Science and Engineering, 662(2): 022126. IOP Publishing.

Lunenburg, F. C. 2010. The Decision Making Process, Natl. Forum Educ. Adm. Superv. J., 27: 1-11, 2010.

Priladha, A., and Setiyadi, A. 2019. Designing Information System Recruitment Professional Gamers Web-Based. In IOP Conference Series: Materials Science and Engineering, 662(2): 022072. IOP Publishing.

Rahim, R., Supiyandi, S., Siahaan, A. P. U., Listyorini, T., Utomo, A. P., Triyanto, W. A., ... and Khairunnisa, K. 2018. TOPSIS Method Application for Decision Support System in Internal Control for Selecting Best Employees. In Journal of Physics: Conference Series, 1028(1): 012052. IOP Publishing.

Setiawan, E. B., and Setiyadi, A. 2018. Web Vulnerability Analysis and Implementation. In IoP Conference Series: Materials Science and Engineering, 407(1): 12081.

Setiyadi, A., and Agustia, R. D. 2018. Penerapan Metode Ahp Dalam Memilih Marketplace E-Commerce Berdasarkan Software Quality and Evaluation Iso/Iec 9126-4 Untuk Umkm. IKRA-ITH INFORMATIKA: Jurnal Komputer dan Informatika, 2(3): 61-70.

Setiyadi, A., and Setiawan, E. B. 2018. Information System Monitoring Access Log Database on Database Server. In IOP Conference Series: Materials Science and Engineering, 
407(1): 012110. IOP Publishing.

Setiyadi, A., and Setiawan, E. B. 2019. Blind scanner Server and Batch Programming Implementation in the Process of Automatically Scan Documents. In IOP Conference Series: Materials Science and Engineering, 662(2): 022068. IOP Publishing.

Setiyadi, A., and Setiawan, E. B. 2020. Private Cloud Development in West Java Cooperative and Entrepreneurship Education and Training Center. In IOP Conference Series: Materials Science and Engineering, 879(1): 012036. IOP Publishing.

Sucipto, S., and Wibisono, D. K. 2019. Implementation of Topsis Method Selection of Student Achievement Lane Stmik Pringsewu. IJISCS (International Journal of Information System and Computer Science), 3(1): 27-35.

Tarigan, A. K., Sagala, S., Samsura, D. A. A., Fiisabiilillah, D. F., Simarmata, H. A., and Nababan, M. 2016. Bandung City, Indonesia. Cities, 50: 100-110.

Van Stel, A., Carree, M., and Thurik, R. 2005. The effect of entrepreneurial activity on national economic growth. Small business economics, 24(3): 311-321. 